\title{
Muskel- og skjelettlidelser som årsak til sykefravær og uføreytelser
}

\author{
Sammendrag \\ Bakgrunn. Muskel- og skjelettlidelser \\ er en heterogen gruppe tilstander. \\ Vi ønsket å beskrive variasjonen \\ i trygdeytelser når det gjelder de hyp- \\ pigst forekommende lidelsene.
}

Materiale og metode. Studien er basert på data fra NAVs registre over sykepenger og uføreytelser.

Resultater. Blant muskel- og skjelettsykdommene er korsryggslidelser den hyppigste medisinske årsaken til sykefravær og uføreytelser og svarer for henholdsvis $11 \%$ og $9 \%$. I tillegg er nakke- og skulderlidelser vanlige årsaker til sykefravær, mens artrosetilstander og fibromyalgi er vanlige når det gjelder uføreytelser, der begge forårsaker $5 \%$ av nye tilfeller.

Fortolkning. Arbeids- og velferdsetaten må fortsatt rette oppmerksomheten mot muskel- og skjelettlidelser for å forebygge langvarig fravær fra arbeid og permanent utstøtning.

\section{Søren Brage}

soren.brage@nav.no

Utredningsseksjonen

Arbeids-og velferdsdirektoratet

Postboks 5 St. Olavs plass

0130 Oslo

\section{Camilla Ihlebæk}

Helse UMB, forskergruppe for natur, helse og livskvalitet

Universitetet for miljø- og biovitenskap, Ås og

Forskningsenhet for stress, helse og rehabilitering

Uni helse, Bergen

\section{Bård Natvig}

Nasjonalt revmatologisk rehabiliterings-

og kompetansesenter (NRRK)

Diakonhjemmet Sykehus

og

Seksjon for sosialmedisin

Avdeling for allmenn- og samfunnsmedisin

Institutt for helse og samfunn

Universitetet i Oslo

\section{Dag Bruusgaard}

Seksjon for sosialmedisin

Avdeling for allmenn- og samfunnsmedisin Institutt for helse og samfunn

Universitetet i Oslo

Muskel- og skjelettlidelser er utbredt, og flere undersøkelser tyder på at forekomsten av slike plager holder seg stabil i befolkningen over tid $(1,2)$. De psykiske lidelsene er blitt vanligere som årsak til trygdeytelser (3), men det er fortsatt slik at muskel- og skjelettlidelser hyppigere er den medisinske årsak til sykefravær og uføreytelser (4).

Muskel- og skjelettlidelsene en heterogen gruppe med henblikk på både kronisitet og på betydning for arbeidsførheten. Vi har sett på hvor ofte muskel- og skjelettlidelser forekommer som medisinsk årsak til henholdsvis sykefravær og uføreytelser.

\section{Materiale og metode}

NAVs registre inneholder opplysninger om diagnoser ved trygdeytelser. Fra sykepengeregisteret ble det hentet ut data over avsluttede sykepengetilfeller blant lønnstakere i 2008 ( $\mathrm{N}=469732)$, inklusive medisinsk sykmeldingsgrunn, kodet etter ICPC-2. Fra uføreregistret ble det hentet alle nye tilfeller av varig uførepensjon og tidsbegrenset uførestønad i $2006(\mathrm{~N}=31600)$, inklusive hovedårsak til uførheten, kodet etter ICD10. Grunnen til at året 2006 ble valgt var mangelfulle diagnoseopplysninger i registeret i 2007-08 ved studiens gjennomførings- tidspunkt. Varig uførepensjon og tidsbegrenset uførestønad er slått sammen og benevnes «uføreytelse».

Kodene for muskel- og skjelettsykdommene ble gruppert for å fange opp hyppig forekommende og likeartede tilstander. De enkelte gruppene med tilhørende koding er beskrevet i tabell $1 \mathrm{og}$ tabell 2. Samsvaret mellom ICPC-2 og ICD-10 er mangelfullt, og diagnosegruppene har derfor fătt noe ulike benevnelser for henholdsvis sykefravær og uføreytelser.

\section{Resultater}

Muskel- og skjelettlidelser var den medisinske årsak i $35 \%$ av sykepengetilfellene i 2008 og i $30 \%$ av de nye tilfellene av uføreytelser i 2006.

Rygglidelser dominerte som årsak både til sykefravær og uføreytelser. To tredeler av det ryggrelaterte sykefraværet var forårsaket av ryggsyndromer uten utstråling, resten av syndromer med utstråling. For uføreytelser svarte lumbale skiveprolapser og isjias for nesten halvparten av de ryggrelaterte ytelsene, resten utgjorde uspesifiserte ryggsmerter og lumbago samt andre rygglidelser, slik som spinal stenose.

Nakkelidelser var vanlig årsak til både sykefravær og uføreytelser - $3,8 \%$ av alle sykepengetilfeller og $3 \%$ av alle nye tilfeller av uføreytelser. Revmatiske sykdommer lå bak $1 \%$ av sykepengetilfellene og $2 \%$ av nye uføreytelser. Artrose var betydelig vanligere som årsak til uføreytelse enn til sykefravær og lå bak $5 \%$ av alle nye ytelser. Noe av denne forskjellen skriver seg fra at artrose i ryggsøylen klassifiseres som rygglidelse i ICPC-2.

Fibromyalgi var medisinsk årsak i 1,9\% av sykepengetilfellene, men diagnosen førte til $5,4 \%$ av alle nye uføreytelser.

Gruppen bursitt/tendinitt/synovitt (entesopatier) og lateral epikondylitt var til sammen

\section{Hovedbudskap}

- Muskel-og skjelettlidelser er hyppigste medisinske årsak til sykefravær og uføreytelser

- Nakke- og skulderlidelser er vanlige årsaker til sykefravær, men har mindre betydning når det gjelder uføreytelser

- De revmatiske lidelsene er viktige for uføreytelsene, men er ikke hyppig årsak til sykefravær 
årsak til 3,2 \% av alt sykefravær, men diagnosene var ikke vanlige som årsak til nye uføreytelser. Brudd, forstuvninger og andre skader i muskel- og skjelettsystemet svarte for $6,3 \%$ av alt sykefravær (ikke vist i tabell). Symfyseløsning førte sjelden til uføreytelser senere, i 2006 var det bare 40 kvinner som fikk uføreytelse på grunn av denne tilstanden.
Tabell 1 Muskel- og skjelettlidelser. Antall avsluttede sykepengetilfeller blant lønnstakere i 2008, med diagnosefordeling i prosent

\section{Sykepengetilfeller 2008}

\begin{tabular}{lrrr} 
Diagnosegruppe & ICPC-2-kode & Antall & Andel (\%) \\
\hline Rygglidelser uten utstråling & L02-L03, L84 & 33600 & 7,2 \\
\hline Rygglidelser med utstråling & L86 & 16350 & 3,5 \\
Kyfose, lordose og skoliose & L85 & 156 & 0,0 \\
Sum rygglidelser & & 50106 & 10,7 \\
\hline Nakkelidelser & L01, L83 & 17704 & 3,8 \\
\hline Skulderlidelser & L08, L92 & 22242 & 4,7 \\
\hline Revmatiske sykdommer & L88 & 4908 & 1,0 \\
\hline Artrose & L89-L91 & 8558 & 1,8 \\
Osteoporose & L95 & 100 & 0,0 \\
\hline Fibromyalgi & L18 & 8787 & 1,9 \\
\hline Bursitt/tendinitt/synovitt & L87 & 9392 & 2,0 \\
\hline Lateral epikondylitt & L93 & 5599 & 1,2 \\
\hline Andre muskel- og skjelettlidelser & Rest av L00-L99 & 35241 & 7,5 \\
\hline Sum alle muskel- og skjelettlidelser & & 162637 & 34,6 \\
\hline Alle lidelser & & 469732 & 100,0
\end{tabular}

Tabell 2 Muskel- og skjelettlidelser. Antall nye tilfeller av uføreytelser ${ }^{1}$ i 2006, med diagnosefordeling i prosent

Nye uføreytelser 2006

\begin{tabular}{|c|c|c|c|}
\hline Diagnosegruppe & ICD-10-kode & Antall & Andel (\%) \\
\hline $\begin{array}{l}\text { Uspesifiserte ryggsmerter } \\
\text { og lumbago }\end{array}$ & M532, M539, M540, M545-549 & 619 & 2,0 \\
\hline Lumbalt skiveprolaps og isjias & M51, M541, M543-544 & 1279 & 4,0 \\
\hline Spinal stenose & M480 & 235 & 0,7 \\
\hline Skoliose & M41 & 43 & 0,1 \\
\hline Andre rygglidelser & $\begin{array}{l}\text { M40, M42, M430-432, M435-439, } \\
\text { M46-47, M481-489, M533-538 }\end{array}$ & 568 & 1,8 \\
\hline Sum rygglidelser & & 2744 & 8,6 \\
\hline Nakkelidelser & M433-434, M50, M530-531, M542 & 948 & 3,0 \\
\hline Skulderlidelser & M75 & 738 & 2,3 \\
\hline Revmatoid artritt & M05-06 & 407 & 1,3 \\
\hline Juvenil artritt & M08 & 14 & $<0,1$ \\
\hline Bekhterevs sykdom & M45 & 213 & 0,7 \\
\hline Artrose & M15-19 & 1577 & 5,0 \\
\hline Osteoporose & M80-81 & 53 & 0,2 \\
\hline Fibromyalgi/myalgi & M79 & 1706 & 5,4 \\
\hline Tendinitt, bursitt, synovitt & $\begin{array}{r}\text { M65-67, M70-72, M760-770, } \\
\text { M772-779 }\end{array}$ & 161 & 0,5 \\
\hline Lateral epikondylitt & M771 & 84 & 0,3 \\
\hline Andre muskel- og skjelettlidelser & $\begin{array}{r}\mathrm{M} 00-02, \mathrm{M} 07, \mathrm{M} 10-13, \mathrm{M} 20-25 \\
\mathrm{M} 30-35, \mathrm{M} 60-62, \mathrm{M} 83-99\end{array}$ & 886 & 2,8 \\
\hline Sum muskel- og skjelettlidelser & & 9531 & 30,2 \\
\hline Piskesnertskade i nakke & S134 & 213 & 0,7 \\
\hline Symfyseløsning ved svangerskap & 0267 & 40 & 0,1 \\
\hline Sum alle lidelser & & 31600 & 100,0 \\
\hline
\end{tabular}

1 «Uføreytelser» inkluderer både varig uførepensjon og tidsbegrenset uførestønad

\section{Diskusjon}

Rygglidelser er fortsatt den dominerende sykdomsgruppen innenfor muskel- og skjelettsystemet hva gjelder trygdeytelser. Siden år 2000 har det imidlertid vært en markert nedgang $\mathrm{i}$ antall tilfeller der rygglidelse har vært årsak til sykefravær og til uføreytelser. En slik nedgang har også vært sett i andre europeiske land, særlig i Storbritannia (5). Som årsak har vært nevnt endringer $\mathrm{i}$ behandlingen av rygglidelser - at man i større grad legger vekt på at pasienten skal opprettholde normal aktivitet og anbefaler rask tilbakegang til arbeid.

For sykefraværet er rygglidelser uten utstråling av størst betydning, mens isjias og lumbale prolapser er viktigere når det gjelder langvarige ytelser. For denne sistnevnte gruppen bør NAVs arbeid rettes mot forebyggende, tidlige tiltak (inklusive yrkesrettet rehabilitering) for å forhindre varig utstøtning fra arbeidslivet.

Nakke- og skulderlidelser samt entesopatier er ofte årsak til sykefravær, men har mindre betydning når det gjelder uføreytelser. Mange av disse tilstandene er kortvarige, og det kan være forholdsvis enklere å tilrettelegge arbeidet for slike plager. I oppfølgingen av de sykmeldte er det viktig at pasienter med denne gruppen av muskel- og skjelettlidelser mobiliseres så raskt som mulig.

De revmatiske lidelsene, artrose og fibromyalgi er sterkt fremtredende når det gjelder langvarige ytelser, men har forholdsvis beskjeden betydning for sykefraværet. Som ved enkelte rygglidelser er det en viktig trygdemedisinsk oppgave å identifisere dem så tidlig som mulig for å kunne sette $\mathrm{i}$ gang forebyggende tiltak. Disse tiltakene inkluderer både medisinsk behandling og rehabilitering og eventuell attføring til mindre belastende arbeid.

\section{Oppgitte interessekonflikter: Ingen}

\section{Litteratur}

1. Ihlebaek C, Brage S, Eriksen HR. Health complaints and sickness absence in Norway, 1996-2003. Occup Med (Lond) 2007: 57: 43-9.

2. Kamaleri Y, Natvig B, Ihlebaek CM et al. Change in the number of musculoskeletal pain sites: A 14-year prospective study. Pain 2009; 141 25-30.

3. Mykletun A. Tiltak for reduksjon i sykefravær: Aktiviserings- og nærværsreform. Ekspertgrupperapport til Arbeidsdepartementet. Oslo: Arbeidsdepartementet, 2010

4. NAV. Sykefraværstilfeller 3 kv 2001 - 2009. www.nav.no/222271.cms (13.9.2010).

5. Waddell G, Aylward M, Sawney P. Back pain, incapacity for work, and social security benefits. London: The Royal Society of Medicine Press, 2002.

Manuskriptet ble mottatt 22.2. 2010 og godkjent 3.6. 2010. Medisinsk redaktør Anne Kveim Lie. 


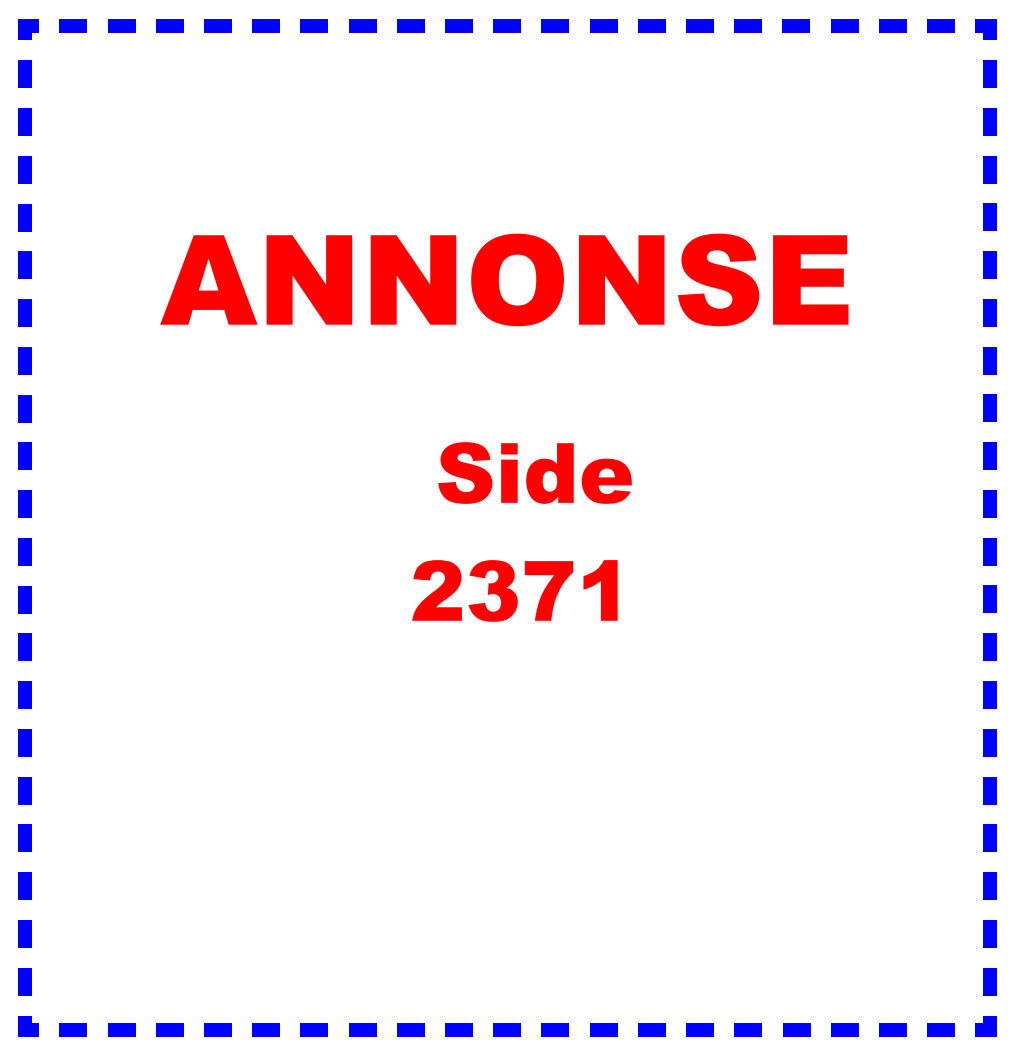

